Issues in theory and methods of teaching foreign languages.

Проблеми теорії і методики навчання іноземних мов

УдК 811.11

https://doi.org/10.31548/philolog2021.03.140

\title{
THE ANALYSIS OF FOREIGN LANGUAGE PROGRAMS FOR THE UNDERGRADUATES - FUTURE SOCIAL WORKERS
}

\author{
K. H. YAKUSHKO, PhD in Pedagogy, Senior Lecturer, \\ National University of Life and Environmental Sciences of Ukraine \\ E-mail:kyakushko@nubip.edu.ua \\ http://orcid.org/0000-0001-6977-8441
}

\begin{abstract}
The article deals with the problem of analysis and comparison of structural and semantic content of foreign language programs to train students of non-philological specialties. The aim of the article is to determine similar and disimilar features of the contexual and structural filling of the foreign language programmes for the seniour students-future social workers within concrete higher educational establishment - National University of Life and Environmental Sciences of Ukraine during 2020/2021 academic year. The result of investigation lays in two conclusions. The first conclusion is that abobenamed educational establishment pays much attention on the foreign language studying through proposing enough studying hours to develop not only direct skills of undergraduates as future entrants to the magistery through the explanation of the method to fill the EVI workbooks up, but also to the general students' philological and creative formation. In parallel it is fixation of attention on certain twelve thematic blocks and grammatical phenomena being related with EVI workbooks as well as repetition, detection and elimination of individual gaps in entering a foreign language environment to be required for the formation of a versatile personality, development of soft skills of every future social worker. The second conclusion is that the programs to train upgraduates- future social workers in different bachelor's training semesters have more common features than distinctive ones. The common features of the fifth, the sixth, the seventh and the eighth semesters of professional social worker's purpose foreign language study are related to ten categories: common assessment policy, common scale of student assessment, total number of modules for each semester, academic loading, previous overall goal, previous general tasks to study professional social worker's purpose foreign language within third or fourth year of studying, relevant subject of discipline and basic competencies, general requirements for the results of certification classes at the end of each module or semester with further clarification of different content as well as the requirement to conclude and present a self-developed thematic presentation or real life story "Once upon a time" and adequate dialogue to discuss current spcial worker's problem by every student almost at every semester. The distinctive features of the fifth, sixth, seventh and eighth semesters of studying a social worker's professional purpose foreign language relate only to three features: modular topics, content and different number of hours to study certain topics. The research perspective is a description of the results of further pedagogical observations in the context of comparative characteristics of foreign language curricula to train undergraduates of other specialties within other higher educational establishments.
\end{abstract}

Keywords: structural and semantic content, foreign language programs, social workers, seniour students, entrance exam for a master's degree program.

Introduction. Nowadays the issue of increasing attention to the process of learning a foreign language by senior students with the forecasting external examinations of nonphilological specialties is actualized because in a year or two such bachelor's program undergraduators will become master's degree program entrants and face the problem of passing a entrance exam in a foreign language.

Resent researches and publications. The interest in formation of a versatile personality, development of soft skills of a future social worker is based on the previous investigations by I. Grabovska [1], dealing with some metacommunicative contact-establishing topicalizing questions in modern English dialogic discourse well as scientific papers by L. Berezova,
A. Polishchuk or K. Yakushko being devoted to the development of soft skills while English preparation for unsergraduates from the Faculty of Land Management [3] or future agroengineer or forester [4], taking into account such features as involvement in general recommendations; approaches methods of filling in EVI notebooks without excessive memorization, parallel refreshment of individual gaps in pronunciation, basics of grammar and vocabulary in composing own statements, etc.

The purpose of the article is to determine similar and disimilar features of the contexual and structural filling of the foreign language 2020/2021 programmes for the seniour students-future social workers within concrete higher educational establishment - National University of Life and 
Issues in theory and methods of teaching foreign languages.

Проблеми теорії і методики навчання іноземних мов

Environmental Sciences of Ukraine during 2020/2021 academic year.

Data and methods. The study was conducted on the basis of syllabi and working curricula for the study of a professional purpose foreign language for future social workers regarding them as the entrants to the master's degree in 2020/2021 academic year. Basic methdos included comparative analysis as well as semantic and syntactic methods, interpretation method.

Results. At first we'd like to represent some found similar features concerning four last semesters of social worker program English bachelor's training during 2020/2021 academic year [2].

In the same way during all abovementioned semesters, the features of deadlines and re-compilation policies are to be revealed (the works being submitted in violation of deadlines without adequate reason are evaluated at a lower grade, and re-assembly of modules is with the permission of the lecturer in substantional need); academic integrity policy (copying during tests and exams is prohibited including the use of mobile devices)as well as the term papers, abstracts must obtain correct text references to the used sources) or attendance policy (attendance is mandatory, but for such objective cases as a disease,international intership, etc. studying may become individual online training after the authorizing by higher educational establishment administration).

Other similar features were noticed either for the fifth, the sixth, the seventh or the eighth semesters of studying a social worker's professional purpose foreign language concerning prescribed assessment scale: the rating of the applicant of higher education in $90-100$ points is projected on such result of passing of examination as "excellent", and credit - as "passed", the student's rating of 74-89 points is correlated with the result of the exam as "good" and the t credit attestation - as "passed", the rating of a bachelor's degree in social work of 60-73 points is the basis to obtain a national grade "satisfactory" on exams and " passed " after credit attestation. Only a low score of 0-59 points is assessed as "unsatisfactory" in the exam and as "not passed" in the credit to become a reason for reassessment.

Besides abovenamed factб the distribution of the workload for professional purpose foreign language studying hours by the undergraduates majoring in social work may be considered to be the same for all semesters, excepting the eighth one: 30 hours of laboratory work and 30 hours of independent work in 2 modules are provided, however the emphasis of strengthening in quantity of independent work in the last eighth semester and distribution of educational loading as 26 hours of laboratory classes and 34 hours of independent work in 2 module was noticed.

Either for the fifth, the sixth, the seventh or the eighth semesters the purpose of the specialty in which a foreign language is not a profile subject, was to train skilled social worker for English professional communication in oral and written forms, to repeat the basics of conversational and professional foreign language speech, taking into account the special features of the vocabulary of the specialty "Social Work", but the sixth semester obtains a projection to get acquainted with the unique foreign language exam requirements being intensified for the seventh or the eighth semesters.

Besides, the previous general tasks of $\mathrm{s}$ a professional purpose foreign language studying for the undergraduates - future bachelors majoring in social work contain the certain task of the discipline of the fifth semester as improving the basic categories of phonetic and grammatical series, as well as mastering the basic colloquial and professional vocabulary and the basic models of word combination; formation of speech skills of foreign language communication. discussion of features of professional activity of social workers through audio perception of foreign speech, conclusion of the presentation, summary, crosswords, carrying out interviews, concluding conversational situations from a real life of the social worker or scenario of a real-life scene and discussing them in dialogue in parallel with acquaintance with the requirements of $\mathrm{EVI}$, mastering the method of performing samples of tasks of the workbook EVI and acquaintance with the material of the textbook to prepare students for external evaluation, mastering the method of filling in the relevant notebooks, elaborating B1 training material for EIT in English. Similar features of the fifth, the sixth, the seventh and the eighth semesters relate to the definition of the subject of the discipline as the formation of knowledge, skills and abilities of conversational and professional foreign language communication after prior acquaintance with resources of electronic course "DAM: GIZ" (Business English: Geodesy and Land Planning", related to the teaching of several specialties due to the universality of thematic content with parallel elaboration of the unique special social worker's vocabulary introduction.

During the study of all these semesters at the end of the bachelor's degree, the future social work specialist is called to gradually develop such knowledge as mastering the basic terminology, auxiliary grammatical structures and clichés of writing their own statements in English on basic information about professions of social worker and entrant to the master's degree and be able to: 
lead a conversation on the topic and the content of texts, show reading, writing, monologue, dialogic speech, listening, teamwork to enter a foreign language environment by Moodle, design and orally defend submitted works prepare thematic reports, dialogues, presentations, write scripts and conversational situations, participate in business games, use basic terminology, and take tests in electronic and face-to-face modes, make statements taking into account the lexical and grammatical features of the materials of preparation for EVI.

The seventh common feature of work programs for the third and fourth year of bachelor's degree in "Social Work" is in general requirements for the results of certification classes at the end of each module or semester with further clarification of different content This feature occurs concerning Topic 5 "E-learn Module1 Test Representing Results of the Module 1 Individual Tasks" to develop the ability to work in the Module 1Moodle system, perform automatic testing, analyze errors for subsequent attempts and the ability to present the results of independent work during an oral interview on the topics of Module1, be able to respond and comment and work on errors in pronunciation, writing and constructing their own sentences in English, the ability to make statements from memory without supporting materials in writing and Topic 8 "E-learn Module2 test. Representing Results of the Module 2 Individual Tasks " with a similar expected result only for the second module and all similar topics at the end of each module and the sixth, seventh and eighth semesters. This identity in the formulation of the expected learning outcomes also applies to the classes that precede the test or exams, for example, on Topic 13, "E-learn Module 3 test"to carry out automatic testing, analyze errors for subsequent attempts., Topic 9 "Preparation to Credit Passing was aimed at mastering the stages and requirements for credit certification, developing the ability to present the results of educational work in the appropriate folder-archive with oral answers to general questions of the course, be able to write a test, topic 18 "Preparation to exam", when waiting for knowledge of the main questions and answers about the content of the course, know the structure of the exam form, know the stages of the exam, be able to apply knowledge in practice trial test, be able to archive the results of work in the appropriate folder and identical topics in other modules.

The eighth common feature is in the presence of the requirement to conclude and present a self-developed thematic presentation by each student in each semester, except the last, for example, when studying Topic 4 "The Demands to Presentation" - with the knowledge of basic presentation requirements, be able to develop and present of the specified requirements concerning the description of features of native region, prospects of establishment of business relations and a field of activity of the social worker, theme 16 The ninth common feature is the requirement to compile and present a selfdeveloped real-life story "Once..." and a certain appropriate dialogue-discussion of current problems of the social worker by each student almost every semester, for example, when studying Topic 7 of the fifth semester " Project dialogue "or topics of the seventh semester (aimed at gaining knowledge about the main types of questions, be able to conclude a conversational situation with Once..." and dialogue to discuss it, discuss it using colloquial expressions related to the professional activities of a social worker in subgroups.

The tenth common feature -echoed the theme of the presence of impregnations in the two semesters of each academic year of listening and working with the table of communicative intentions. For example, the topic Topic 6 of the fifth semester is related to a similar topic3 of the seventh semester "50 Spread Phrases, Main Communicative Intentions and Basic Social Work Terms in own Speech", the expected result of mastering was application of knowledge about the basic terms of social work when composing their own sentences, along with common colloquial expressions to represent different communicative intentions. After mentioning similar stuctural and contexual program features it'a a time to represent some found disimilar concerning four last semesters of social worker's program English bachelor's training during 2020/2021.

The disimilar features of the fifth, sixth, seventh and eighth semesters of studying a foreign language in the professional direction of undergraduates in the specialty "Social Work" of the bachelor's degree relate to only three features: modular topics, content and different number of hours to study certain topics such as the first module "Introduction. Presentation. Interview "of the fifth semester on each of the following topics, except for the last two, 2 hours for laboratory and 2 hours for independent work. Topic 1 Introduction, Topic 2 "The First Impression, My Personality in Symbols", Topic 3 "Journalist's Interviewing and Conclusions with 4 hours for laboratory and 4 hours for independent work as well as Topic 10 "Social Worker's Major " or A Social Worker's Real Life Project Dialogue "of the fifth semester, Topic 11" EVI demands in Workbook №1 and Workbook №2 "EVI in practice, Module 4ZNO B1 Training (part 1)", Topic 14 "Family and Relationship. People and society ", Topic 15 "Home .School", Topic 7 "EVI demands in Workbook № 3 and Workbook № 4", 
Topic 9 (4/4 hours) "Healthy Living.Travel and Tourism» "EVI Exam Demands and Preparation (Part 3)", Topic 12 "EVI Demands in Workbook 5 and Workbook № 6" (4/6 hours), Topic 14 (4/4 hours) "Science and Technology. Nature and Environment", Topic 16 "Vocabulary Dictation, the Review of all Course topics in Dialogues-Practical Situations (2/4 hours) etc.

Discussion. Thus, the first conclusion is that the National University of Life and Environmental Sciences of Ukraine pays much attention on the foreign language studying through proposing enough studying hours to develop not only direct skills of undergraduates as future entrants to the magistery through the explanation of the method to fill the EVI workbooks up, but also to the general students' philological and creative formation in parallel with the fixation of attention on certain twelve thematic blocks and grammatical phenomena being related with EVI notebooks as well as repetition, detection and elimination of individual gaps in entering a foreign language environment to be required not only for mechanical filling of EVI workbooks but for the formation of a versatile personality, development of soft skills of every future social worker. The second conclusion of the article is that the programs to train upgraduates - future social workers in different bachelor's training semesters have more common features than distinctive ones. The common features of the fifth, the sixth,

\section{References}

1. Grabovska, I. V. (2019). Metacommunicative contact-establishing topicalizing questions in modern English dialogic discourse. International journal of philology. 10 (1), 38-41. DOI: http://dx.doi.org/ 10.31548/philolog2019.0 1.038

2. Yakushko, K. H., (2021). Dilova anglijska mova: geodeziya ta zemleustrij. [English business course: geodesy and land planning]. URL: https://elearn.nubip.edu.ua/course/ view.php?id=1032

3. Yakushko, K. H. (2021). Osoblyvosti organizatsii vyvchennia anglijskoji movy studentamy drugogo kursu fakultety zemlevporiadkuvannia Natsionalnogo universytetu bioresursiv I pryrodokorystuvannia Ukrainy [Special features to organize foreign language studying by the second-year students of the the seventh and the eighth semesters of professional social worker's purpose foreign language study are related to ten categories: common assessment policy, common scale of student assessment, total number of modules for each semester, academic loading, previous overall goal, previous general tasks to study professional social worker's purpose foreign language within third or fourth year of studying, relevant subject of discipline and basic competencies, general requirements for the results of certification classes at the end of each module or semester with further clarification of different content as well as the requirement to conclude and present a self-developed thematic presentation or real life story "Once upon a time"and adequate dialogue to discuss current spcial worker's problem by every student almost at every semester. The distinctive features of the fifth, sixth, seventh and eighth semesters of studying a social worker's professional purpose foreign language relate only to three features: modular topics, content and different number of hours to study certain topics. The research perspective is a description of the results of further pedagogical observations in the context of comparative characteristics of foreign language curricula to train undergraduates of other specialties within other higher educational establishments.

Faculty of Land Management within the National University of Life and Environmental Sciences of Ukraine]. New impetus for the advancement of pedagogical and psychological sciences in Ukraine and EU countries: research matters: collective monograph. Vol. 2. Riga, Latvia: Baltija Publishing. 397-426

4. Yakushko, K. H., Polishchuk, A. V., Berezova, L. V. (2021). Tematyka kursiv inozemnoji movy dlia starshokursnykiv spetsialnosti 'Geodeziya ta zemleustij". [Foreign language courses themes for the seniour students in specialty "Geodesy and Land Planning"]. International journal of philology. 12 (2). URL:: http://journals.nubip.edu. ua/index.php/ Filol/article/view/15024. DOI: http://dx.doi.org /10.31548/philolog2021.02.126

\section{АНАЛІЗ ПРОГРАМ ВИВЧЕННЯ ІНОЗЕМНОЇ МОВИ МАЙБУТНІМИ СОЦІАЛЬНИМИ РОБІТНИКАМИ НА СТАРШИХ КУРСАХ БАКАЛАВРАТУ К. Г. Якушко}

Анотація. Стаття дотична до проблеми аналізу та порівняння структурно-семантичного наповнення програм з іноземної мови для підготовки студентів нефрілологічних спеціальностей. Метою статті є визначення спільних та відмінних рис у змістовому та структурному наповненні програм вивчення іноземної мови старшокурсниками-майбутніми соціальними робітниками за у певному закладі вищої освіти - Національному університеті біоресурсів і природокористування України протягом 2020-2021 н. р. Результатом дослідження $є$ два висновки. Першим висновком 
Issues in theory and methods of teaching foreign languages.

Проблеми теорії і методики навчання іноземних мов

статmі є те, що означений вище заклад вищої освіти приділяє значну увагу вивченню іноземної мови через виділення достатньої кількості годин навчального навантаження для розвитку не лише безпосередніх вмінь старшокурсників як майбутніх абітурієнтів магістратури через пояснення методики заповнення робочих зошитів ЄBI. Достатня увага приділяється загальному фрілологічному та творчому формуванню студентів. Паралельно фріксується уваги на певних дванадиятьох тематичних блоках та поширених в зошитах $€ B I$ граматичних явищах. Виявляються та усуваються індивідуальні прогалини входження в іншомовне середовище задля становлення різнобічної особистості, вироблення soft skills майбутнього соціального робітника. Другим висновком статті $\epsilon$ те, що, що програмам підготовки соціальних робітників під час вивчення іноземної мови за профресійним спрямуванням на старших курсах бакалаврату притаманна більша кількість спільних рис, аніж відмінних. Спільні риси щодо п'ятого-восьмого семестрів вивчення іноземної мови за профресійним спрямуванням старшокурсниками спеціальності «Соціальна робота» бакалаврату дотичні до десятьох категорій: спільної політики оцінювання, спільної шкали оцінювання студентів, спільної кількості модулів для опрацювання у кожному семестрі,навчального навантаження, попередньої загальної мети, попередніх загальних завдань вивчення іноземної мови за професійним спрямуванням на третьому та четвертому курсах навчання на гуманітарно-педагогічному фракультеті Національного університету біоресурсів $i$ природокористування України, відповідного предмету дисципліни та базових компетенцій, загальних вимог до результатів атестаційних занять наприкінці кожного модуля або семестру з подальшим уточненням різного змістового контенту та наявності вимоги укладання та представлення самостійно розробленої тематичної презентації, історії з реального життя «Одного разу...» та певного відповідного діалогу-обговорення поточних проблем соціального робітника кожним студентом майже у кожному семестрі. Відмінні риси щодо п'ятого- восьмого семестрів вивчення іноземної мови за професійним спрямуванням старшокурсниками спеціальності «Соціальна робота» бакалаврату стосуються у цілому тільки трьох особливостей: помодульної тематики занять, змістового наповнення та різної кількості годин на опрацювання певних тем. Перспективою досліджень $є$ опис результатів подальших педагогічних спостережень у контексті порівняльних характеристик навчальних планів з іноземної мови для підготовки старшокурсників інших спеціальностей в інших закладах вищої освіти.

Ключові слова: змістовне наповнення, структура програми з іноземної мови, соціальні робітники, старшокурсники бакалаврату, єдиний вступний іспит у магістратуру. 